\title{
What do people do at work?
}

\section{A profile of U.S. jobs from the survey of workplace Skills, Technology, and Management Practices (STAMP)}

\author{
Michael J. Handel ${ }^{1}$
}

Accepted: 3 August 2016 / Published online: 4 October 2016

(c) The Author(s) 2016. This article is available at SpringerLink with Open Access.

\begin{abstract}
This paper describes the survey of Skills, Technology, and Management Practices (STAMP), which emphasizes the use of behaviourally specific questions in order to improve the quality of job measures. Such measures yield better understanding of the absolute levels of job demands compared to items or scales with arbitrary units that lack definite meaning outside the framework of a particular survey. STAMP measures reveal most workers use relatively simple levels of math on their jobs, but there is a bifurcation of jobs in terms of the complexity of reading and especially writing that is required. Aside from managerial and professional occupations, the absolute level of academic skills required on most jobs does not appear to be very high. Likewise, computer use is widespread but most people use computers for fairly mundane office duties rather than more complex tasks; few workers use any kind of automated production equipment on their jobs. Well-developed employee involvement practices, such as self-directed teams, cover about one-fifth to one-quarter of the workforce. Very few workers report being affected by outsourcing and the numbers affected by technological displacement are almost imperceptible.
\end{abstract}

\section{Was machen Menschen bei der Arbeit?}

Ein Profil US-amerikanischer Arbeitsplätze aus der Untersuchung von Kompetenzen, Technologie und Managementpraktiken am Arbeitsplatz (Skills, Technology, and Management Practices - STAMP)

Michael J. Handel

m.handel@neu.edu

1 Department of Sociology and Anthropology, Northeastern University, 960B Renaissance Park, Boston, MA 02115, USA
Zusammenfassung Die vorliegende Abhandlung beschreibt die Untersuchung von Kompetenzen, Technologie und Managementpraktiken (Skills, Technology, and Management Practices - STAMP), die die Nutzung verhaltensspezifischer Fragen als ein Mittel unterstreicht, um die Qualität von Arbeitsplatzmaßnahmen zu verbessern. Solche Maßnahmen führen zu einem besseren Verständnis der absoluten Arbeitsanforderungen im Vergleich zu Skalen mit willkürlichen Einheiten, die außerhalb einer speziellen Studie keine eindeutige Bedeutung haben. STAMP-Maßnahmen zeigen, dass die meisten Angestellten einfache Mathematik für ihre Arbeit nutzen. Zugleich gibt es zwei Gruppen von Arbeitsplätzen im Hinblick auf die Komplexität der erforderlichen Kompetenzen im Bereich Lesen und insbesondere Schreiben. Abgesehen von Managementpositionen und Fachkräften erscheint das absolute Niveau an theoretischen Kenntnissen, das für die meisten Arbeitsplätze erforderlich ist, nicht sonderlich hoch. Ebenso ist die Nutzung von Computern weit verbreitet, wobei die meisten Menschen Computer für eher schlichte Büroarbeiten verwenden als für komplexere Aufgaben; nur wenige Arbeitnehmer nutzen Formen automatisierter Betriebsmittel bei ihrer Arbeit. Fortgeschrittene Methoden zur Mitarbeiterbeteiligung wie eigenständige Teams betreffen rund ein Fünftel bis ein Viertel der Erwerbstätigen. Sehr wenige Arbeitnehmer berichten, dass sie direkt von Outsourcing betroffen sind und die Anzahl derer, die ihren Arbeitsplatz verlieren, weil ihre Aufgaben von neuen Technologien übernommen werden, ist verschwindend gering.

\section{Introduction}

Researchers across several fields, including sociology, labour economics, education, and public policy, are keenly 
interested in understanding levels and trends in job skill requirements, and their relationships to technology and work organization. The nature of job skill requirements is central to a number of broader research topics in the United States and elsewhere, notably ...

- the growth of wage inequality since the late 1970s, which some have ascribed to a technologically-induced skills shortage (Katz and Murphy 1992; Danziger and Gottschalk 1995; Autor, Katz, and Krueger 1998; Morris and Western 1999; Fernandez 2001; Bresnahan et al. 2002).

- persistently disappointing earnings and employment prospects of less-skilled workers (Holzer 1996).

- persistent racial inequality and high poverty levels, and concern over the movement of persons from welfare to rewarding work (Wilson 1996; Moss and Tilly 2001; Holzer and Stoll 2001).

- potential for remediation of inequality through improved education, smoother transitions from school to work, and diffusion of employee involvement or "high performance" workplace practices (Murnane and Levy 1996; Rosenbaum and Binder 1997; U.S. National Commission on Excellence in Education 1983; Smith 1997; Appelbaum, Bailey, Berg, and Kalleberg 2000; Osterman 2000).

- concern over the possibility of various forms of job degradation (routinization, effort intensification, outsourcing, precarity, lower real wages and benefits) resulting from the adoption of "lean and mean" organizational reforms (Harrison and Bluestone 1998; Harrison 1994; Graham 1993; Green 2006; Handel 2005a).

All of this research rested on theories, findings, or assumptions regarding the nature, level, and trend of job skill requirements. However, a longstanding problem was that most of these studies used either rough proxy measures of job skill demands available in nationally representative data sets (broad occupation group, personal education, average education within occupations), occupation-level job measures from individual cross-sections (e.g., DOT or O*NET scores $)^{1}$, or, more rarely, case-level measures created for unique surveys administered to restricted samples (Holzer 1996; Fernandez 2001). Other research used open-ended and relatively unstandardized interview methods for qualitative cases studies (e.g., Rosenbaum and Binder 1997), while reports of high-level commissions resting on a thin base of impressionistic evidence and speculative assumptions have long been a staple of the policy discourse providing indirect impetus for the academic research (e.g., U.S.

${ }^{1} D O T=$ Dictionary of Occupational Titles, $O * N E T=$ Occupational Information Network.
Department of Labor. Secretary's Commission on Achieving Necessary Skills 1991). No systematic portrait of U.S. jobs had been produced since the final Quality of Employment Survey in 1977 (Quinn and Staines 1978).

In addition, survey questions on job skill requirements and other characteristics tended to use overly general wording and subjective scales (e.g., rating scales, vague quantifiers), which are less interpretable than more behaviourally specific measures and subject to significant measurement error (Handel 2000, 2008). In many ways O*NET maintains some of these limitations (see Handel, this issue). ${ }^{2}$ Likewise, almost no survey, including $\mathrm{O} * \mathrm{NET}$, has equally strong coverage of (1) job skill requirements, (2) technology use, and (3) employee involvement (EI) practices despite their presumed importance and interrelationships. Consequently, researchers have only a cloudy sense of the levels and kinds of job skill requirements, rates of change, the dimensions along which job skills are changing, and the interrelationships between skills, technology, and EI. If current concerns are to be addressed with any degree of specificity, measures of job requirements need to be more precise, concrete, and comparable to person characteristics covering all three of the key content areas, so that researchers and users of research have some notion of the absolute levels of job demands, rather than just a score on a rating scale that has no clear meaning outside the framework of a particular survey.

With these goals in mind, the survey of Skills, Technology, and Management Practices (STAMP) was developed to collect direct information on job skill requirements, technology use, employee involvement practices, and other job characteristics that have been subjects of broad interest for many years.

In particular, STAMP was designed to address the following questions:

1. What is the distribution of jobs by level of skills, computer use $^{3}$, and participation in employee involvement practices? In other words, what is the skill profile of the American job structure?

2. What are the functional and causal relationships between skill requirements, computer use, and employee involvement?

3. What are the effects of skill requirements, computer use, and EI on wages, working conditions, and other job char-

\footnotetext{
${ }^{2}$ For example, O*NET's measures of math, reading, and writing used at work are rating scales that do not correspond clearly to different objective levels of complexity or easily understood categories of educational achievement. Other important job characteristics are beyond O*NET's scope altogether, such as promotion opportunities, downsizing/outsourcing, workload, work pace, stress, and pay and benefits.

${ }^{3}$ For ease of exposition, "computer use" is sometimes used as a shorthand to refer to the broader category "computer and other technology use.".
} 
acteristics (e. g., work intensity, promotions, layoffs, outsourcing, unionization, job satisfaction)?

4. What are the trends in ...

1. skill requirements, technology, and EI practices?

2. their functional and causal interrelationships?

3. their relationships to the other outcomes noted in (3) above?

One of the most active research programs on job skill requirements using individual-level data that pre-dates STAMP is based on the UK Skills and Employment Surveys (see Felstead et al. 2007 and Green et al. 2016). The past decade has seen a significant increase in awareness regarding the critical importance of measuring job characteristics effectively for research, which has stimulated studies using the German Qualification and Career Surveys (see Spitz-Oener 2006 and Rohrbach-Schmidt and Tiemann 2016). This movement has culminated in the recent multi-country Survey of Adult Skills, coordinated by the OECD (OECD 2012), whose section on job requirements draws from both the UK Skills and Employment Surveys and STAMP. The World Bank's multi-country Skills Toward Employment and Productivity (STEP) survey relies even more heavily on STAMP (see Handel et al. 2016).

This paper is an overview of STAMP results that provide a systematic profile of the American job structure that can serve as a basis for discussions of the skill requirements of American jobs. The goal is primarily descriptive, with tentative implications for other issues noted as they arise. The next section describes the STAMP approach to improving upon existing measurers of job content. The following section describes the sample and potential implications for estimates of job requirements in the U.S. The remaining sections presents results on skill requirements, technology use, employee involvement, and other management practices, respectively. A final section concludes.

\section{Development of the STAMP survey}

STAMP sought to improve upon existing survey approaches in a number of ways. To avoid the thinness of some recent surveys, STAMP focused on achieving high content validity by covering as much ground with as much detail as possible in all three of the core domains (skills, technology, EI). Items were constructed to measure a wide range of levels within different constructs to maximize variability and precision and to avoid problems with coarse scales, highly skewed response distributions, and floor and ceiling effects.

STAMP also adopted a measurement strategy that can be called explicit scaling (Handel 2008, 2016). In contrast to previous approaches, survey questions and response options were made as concrete, factual, and specific as possible to minimize error variance due to subjective and inconsistent interpretations of their meanings across respondents. Questions were phrased in terms of facts, events, and behaviours rather than attitudes, judgments and evaluations, wherever possible. The survey uses response scales with cardinal or other absolute meanings and avoids vague quantifiers and numerical rating scales wherever possible. These kinds of responses are more interpretable than five-point rating scales or factor-analytic scales. Ideally, job requirements are measured on the same scale as person abilities, such as education levels or weight of loads lifted on the job, which permits direct comparisons of jobs and workers. Of course, not all items can achieve this level of concreteness while remaining generally valid for the diverse jobs found in a modern economy, but items that are behaviourally explicit and response options with absolute meanings are the ideals that guided the survey construction. The Appendix contains text of key questions. Rating scales are not completely absent from STAMP, but the goal is to minimize their use in favor of questions and response scales that have objective meanings.

STAMP items were developed from a wide literature search across various disciplines (sociology, industrial relations, labour economics, education, psychology, human resource management), my own experience working with existing surveys (Handel 2000, 2006), recent research on survey methodology, and a pilot version of the survey administered by graduate students in face-to-face interviews with over one hundred workers in diverse occupations in a medium-sized urban area. Late-stage versions of the instrument were circulated to other researchers, most with extensive experience conducting work-related surveys, and their comments were incorporated into the final survey. ${ }^{4}$

Separate analyses indicate that the validity and reliability of the STAMP measures is generally high (Handel 2008, 2016). Multiple items intended to measure the same construct usually scale strongly with one another using multiple tests of construct validity (Cronbach's $\alpha$, nonlinear principal components analyses, confirmatory factor analysis). Some items form Guttman-style hierarchies of intensity, in which people responding positively to higher-level items (e. g., use calculus) have a high probability of responding positively to all lower-level items (e.g., perform multiplication/division). This kind of scale is considered to meet stricter standards of unidimensionality in measuring latent traits than more common form of scales using a number of parallel measures. The scales also correlate strongly with

\footnotetext{
${ }^{4}$ I would like to thank in particular Mary Ellen Colten and Carol Cosenza of the Center for Survey Research (CSR) (University of Massachusetts-Boston), who helped me revise the pilot version, and Peter Cappelli, Harry Holzer, Arne Kalleberg, Joel Rogers, Nora Cate Schaeffer, Erik Olin Wright, Jonathan Zeitlin, and members of the Economic Sociology Seminar at the University of Wisconsin-Madison for their comments on various survey drafts.
} 
various other measures like required education level and wages, indicating generally strong criterion validity.

One potential limitation of the STAMP approach is that it is based on self-reports of job incumbents, which may be upwardly biased compared to trained job analysts' judgments. Employees may inflate self-reports due to self-presentation motives and restricted frames of reference. When a worker rates their job's level of autonomy, for example, they are more likely to be making comparisons to jobs relatively close to their own, rather than considering where their job falls relative to the entire spectrum of jobs in the economy. Indeed, research finds incumbents generally give their jobs more positive ratings than job analysts or other external observers, such as supervisors, though the two sets of ratings are usually, though not always, correlated and the differences between incumbents and observers are not always large. ${ }^{5}$

However, analyst and supervisor ratings also have potential problems, such as less intimate knowledge of jobs than the job-holders themselves, and biases such as halo effects or stereotyping. ${ }^{6}$ In practice, job analysts themselves usually derive much of their data from interviews with incumbents, though they combine this information with their own and others' observations and judgment, as well.

Hopefully, the concreteness of STAMP questions and response options reduces any upward bias of incumbent selfreports compared to existing survey practices. Nevertheless, it is likely that any self-report item contains some degree of upward bias, which will artificially elevate estimates of average job skill requirements. If individuals with more skills or holding higher positions are also more likely to give self-enhancing responses to measures of job characteristics, then the strength of relationships may also be inflated due to common method variance.

\section{Sample}

STAMP is a two-wave refreshed panel that used randomdigit dial telephone methods to interview employed wage and salary workers in the United States age eighteen and over. The first wave was conducted between October 2004 and January $2006(n=2304)$. Eligible individuals were selected randomly within households and interviewed with

\footnotetext{
5 For examples, see Cook et al. (1981, pp. 173 ff.); Kohn and Schooler (1983, p. 67); Lopata et al. (1985, pp. 404 ff.); Glick et al. (1986, p. 449); Gerhart (1987); Harvey (1991, p. 112); Cully et al. (1999, p. 54); Peterson et al. (1999, pp. 67, 241, 292); Manson et al. (2000, p. 16); Leckie et al. (2001, pp. 49 ff.); Green and James (2003).

${ }^{6}$ For examples, see Cain and Treiman (1981, pp. 269 ff.); Steinberg (1990); Spenner (1983, p. 831); Attewell (1990, p. 429); Peterson et al. (2001, p. 484); Darrah (1994, pp. 73 ff.); Cully et al. (1999, pp. 120, 148, 276 ff.); Spector and Fox (2003, p. 419); Green and James (2003).
}

respect to their own jobs, i. e., no proxy reporting. Between September 2007 and December 2009 respondents from the first wave were reinterviewed, along with a new, representative sub-sample to permit trend analyses as well as fixed effects models for a three-year panel. In the first wave, complete interviews were conducted with $66 \%$ of those deemed eligible after screening. The survey contained about 166 unique items related to job characteristics, as well as others related to personal characteristics; the average interview length was approximately $28 \mathrm{~min}$. All respondents received post-stratification weights to make the sample consistent with contemporaneous data from the U.S. Current Population Survey and all tabulations below are weighted.

To ensure jobs at all skill levels were represented in the survey in proportion to their numbers in the workforce, a Spanish-language version of the survey was administered to workers who were more comfortable taking the survey in Spanish. Nevertheless, it is highly likely that the sample under-represents a large group of low-skill workers eligible for the survey, undocumented Spanish-speaking immigrants, who would be expected to be reluctant to answer job-related questions posed by a stranger over the telephone. Additionally, workers who speak neither English nor Spanish well enough to be interviewed were outside the survey's universe for practical reasons. Only 105 of the households contacted in the first wave were deemed ineligible for language reasons, but many members of this population may lack telephones altogether.

These omissions may have some effect on the results. The large increase in unskilled immigration to the United States in recent years itself somewhat contradicts the widespread notion of skills shortage. Insofar as low-skilled immigrants are under-represented in the sample, results are somewhat biased upward in favour of the conventional wisdom in its estimates of job requirements such as cognitive skills, technology use, and employee involvement. This upward bias is potentially progressive over future waves if the low-skilled immigrant share of the workforce grows significantly over time.

By contrast, any upward biases resulting from incumbents' self-reports will likely difference out in analyses of time trends. There is also little reason to suppose à priori that any variations in self-enhancing biases across skill groups will grow over time.

The exclusion of workers under age eighteen also contributes to upward bias in estimates of mean skill levels, but the shrinking proportion of workers within this age group is likely to reduce this problem over time. 
Table 1 STAMP survey content $(N=$ number of items)
Basic job and organizational information $(N=12)$

Occupation, industry, organizational position, organizational and job tenure, union membership, organizational size, organization type (govt., non-profit, for-profit)

Skill and Task Requirements $(N=60)$

Cognitive skills $(N=48)$

Mathematics $(N=12)$

Reading $(N=8)$

Writing $(N=6)$

Forms and visual matter $(N=6)$

Problem-solving $(N=3)$

Required education, experience, and training $(N=$ 9)

Skill changes in previous three years $(N=4)$

Interpersonal job tasks $(N=8)$

Physical job tasks $(N=4)$

Supervision, Autonomy, Authority $(N=11)$

Closeness of supervision

Repetitive work

Autonomy

Supervisory responsibilities over others

Decision-making authority over organizational policies

Computer and Other Technology $(N=49)$

Machinery and electronic equipment $(N=18)$

Level of machine knowledge needed, training time Stet-up, maintenance, and repair

Computers $(N=26)$

Automation, equipment and tool programming

Frequency of use

Use of fourteen specific applications

Use of advanced program features, and occupationspecific and new software

Training times

Complexity of computer skills required

Adequacy of respondents' computer skills

Computer knowledge and experience in prior jobs among non-users

Other technology $(N=5)$

Telephone, calculator, fax, bar code reader, and medical, scientific and lab equipment

Employee Involvement $(N=18)$

Job rotation and cross-training

Pay for skill

Formal quality control program

Team activity levels, responsibilities, and decision making authority

Bonus and stock compensation

Job Downgrading $(N=15)$

Promotion opportunities

Downsizing, outsourcing, technological displacement

Reductions in pay and retirement and health benefits

Work load, pace, and stress

Strike activity

Job Satisfaction $(N=1)$ 
Table 2 Math, reading, writing, and document use

\begin{tabular}{|c|c|c|c|c|c|c|}
\hline & All & Upper WC & Lower WC & Upper BC & Lower BC & Service \\
\hline Percentage (weighted) & 100 & 36.1 & 25.4 & 10.3 & 13.0 & 15.1 \\
\hline$N$ (unweighted) & 2304 & 1010 & 569 & 161 & 271 & 291 \\
\hline \multicolumn{7}{|l|}{ Math $(\alpha=0.81)$} \\
\hline 1. Any math & 94 & 95 & 97 & 94 & 91 & 88 \\
\hline 2. Add/subtract & 86 & 93 & 90 & 87 & 78 & 73 \\
\hline 3. Multiply/divide & 78 & 89 & 82 & 81 & 65 & 57 \\
\hline 4. Fractions & 68 & 82 & 68 & 70 & 58 & 40 \\
\hline Any more advanced & 22 & 35 & 9 & 41 & 19 & 4 \\
\hline 5. Algebra (basic) & 19 & 30 & 8 & 36 & 16 & 4 \\
\hline 6. Geometry/trig & 14 & 20 & 5 & 29 & 15 & 2 \\
\hline 7. Statistics & 11 & 22 & 5 & 10 & 6 & 2 \\
\hline 8. Algebra (complex) & 9 & 14 & 3 & 16 & 8 & 2 \\
\hline 9. Calculus & 5 & 8 & 1 & 8 & 5 & 1 \\
\hline \multicolumn{7}{|l|}{ Reading $(\alpha=0.80)$} \\
\hline 1. Any reading & 96 & 99 & 97 & 91 & 91 & 95 \\
\hline 2. One page & 82 & 96 & 86 & 72 & 57 & 67 \\
\hline 3. Five pages & 54 & 81 & 47 & 46 & 26 & 32 \\
\hline 4. News articles, et al. ${ }^{a}$ & 42 & 64 & 37 & 27 & 21 & 24 \\
\hline 5. Prof'l articles ${ }^{b}$ & 38 & 65 & 26 & 24 & 15 & 23 \\
\hline 6. Books & 53 & 76 & 40 & 53 & 35 & 38 \\
\hline \multicolumn{7}{|l|}{ Writing $(\alpha=0.64)$} \\
\hline 1. Any writing & 91 & 99 & 93 & 83 & 80 & 83 \\
\hline 2. One page & 61 & 86 & 56 & 46 & 36 & 41 \\
\hline 3. Five pages & 24 & 47 & 13 & 12 & 7 & 9 \\
\hline 4. News articles, et al. ${ }^{\mathrm{a}}$ & 9 & 20 & 4 & 1 & 4 & 3 \\
\hline 5. Books/prof'l arts ${ }^{\mathrm{b}}$ & 3 & 7 & 0 & 0 & 0 & 2 \\
\hline \multicolumn{7}{|l|}{ Documents } \\
\hline 1. Use any forms & 67 & 78 & 77 & 61 & 46 & 46 \\
\hline 4. Form complexity ${ }^{\mathrm{c}}$ & 3.16 & 3.99 & 3.65 & 2.62 & 1.84 & 1.86 \\
\hline
\end{tabular}

Note: All figures are percentages unless noted

${ }^{a}$ Category includes articles or reports for magazines, newspapers, or newsletters

${ }^{b}$ Category includes articles for scholarly, scientific, or professional journals

${ }^{\mathrm{c}}$ Mean values on a rating scale ranging from $0=$ no form use, $1=$ extremely simple, $11=$ extremely complicated

\section{Job skill requirements}

Table 1 presents a summary of the content of the STAMP survey. The survey uses a relatively conventional categorization of work tasks into cognitive, interpersonal, and physical tasks, following the DOT's data, people, and things schema.

Given their centrality to current debates, cognitive skills receive particular attention. The survey uses measures of general human capital that are likely to be meaningful to workers in diverse jobs, such as the levels of math, reading, writing, problem-solving, and the overall level of formal education required for their jobs. Specific human capital is measured using required years of previous experience in related jobs, length of training time for current job, and recent firm-provided training. Other items measure certain skills of low to moderate generality related to the use of computers, heavy equipment, and other technologies. More occupationally-specific items, which are common in applied job analysis, would not be meaningful to most people in a general workforce survey.

The survey also covers other general dimensions frequently considered related to both cognitive skill and work organization, such as autonomy, closeness of supervision, authority, and managerial responsibilities (cf. Spenner 1983; Kohn and Schooler 1983; Peterson et al. 1999, pp. $251 \mathrm{f}$.), as well as employee involvement and various aspects of job downgrading.

The tables present variable means and proportions for the full sample and by broad occupation group for the first survey wave; figures are weighted to ensure representativeness. The occupation groups used in the tables are defined as follows: 
- Upper WC = upper white collar (management, professional, technical occupations).

- Lower WC = lower white collar (clerical, sales).

- Upper BC = upper blue collar (craft and repair workers, e. g., construction trades, mechanics).

- Lower BC = lower blue collar (factory workers, truck drivers, etc.).

- Service $=$ e. g., food service workers, home health care aides, child care, janitors, police and fire fighters.

\subsection{Academic skills: math, reading, and writing}

Academic skills are at the centre of debates over whether the United States suffers from a general skills shortage. Labour economists studying inequality mostly infer rising skill requirements from wage trends. Some social scientists proclaim the rise of an information society led by a new class of knowledge workers, while concerns that American schools are failing to prepare students for this new world of work are rife and have motivated a "back to basics" emphasis on traditional literacy and math skills. Yet hard data and direct measures to test or substantiate these views are scarce.

Just what are the general academic skills that Americans use on their jobs?

Table 2 shows the percentages of workers performing math, reading, and writing tasks on their jobs at various levels. Reading across the rows the percentages generally decline, with some exceptions, because the occupation groups form a rough skill hierarchy. Reading down the columns the percentages generally decline because the STAMP items were constructed to represent a hierarchy of complexity moving from simple to difficult. Figures for Cronbach's $\alpha$ give some indication of the consistency with which the items measure a common latent trait.

Mathematics Almost everyone uses some basic math skills on their job. But once one moves beyond simple tasks like counting, addition/subtraction, and multiplication/division, the proportions begin to drop. Only about two-thirds use fractions, decimals, and percentages, and there is an even clearer break beyond this point. Only $22 \%$ of all workers use more sophisticated mathematics on their jobs, and this most commonly means simple algebra. Relatively few people use more complicated math on the job, even the sort normally taught in high school.

Reading across the rows in Table 2, there is a significant occupational gradient in the use of math that corresponds generally to intuition. One prominent exception is the large proportions of skilled blue collar workers who report using various kinds of math on their jobs, generally comparable to managers and professionals. Both groups use geometry, trigonometry, inferential statistics, and complex algebra at rates varying from about 15 to $30 \%$. For other workers, the percentages performing these tasks are generally in the low single digits.

Only about $5 \%$ of all workers use calculus, which is the only level of math in the list that is clearly college level, at least in the American context. If inferential statistics and advanced algebra were included in that category, usage rates are closer to $10 \%$ for the workforce overall and approximately $15-20 \%$ for workers in the more math-intensive occupational groups. These are measures of job demands. It is useful to recall one measure of the supply of skills, which is that approximately $50 \%$ of Americans have some level of college attainment and would be expected to have some or all of these skills, or easy access to obtaining them in the course of their student careers.

Overall, it seems that rather basic levels of math, corresponding to two years of ordinary high school instruction, are sufficient for most jobs.

Reading Most people are far more likely to report they read than use math as part of their jobs. Almost everyone does some reading on the job, but the numbers begin to drop noticeably for most occupational groups even when the question is reading continuous text that is one page long. Other than managers and professionals, only about $25-45 \%$ of workers read text that is at least five pages long as a regular part of their jobs. For the upper white-collar workers, this figure is over $80 \%$. A large majority of the latter also reads articles in newspapers and trade magazines, articles in professional journals, and books as a regular part of their job. In general, only one-quarter to one-third of workers in other occupations read material at that level of complexity. Overall, approximately $40-50 \%$ report reading what may be relatively complex material, but the numbers vary significantly by occupation group.

The percentages reporting reading professional journals and books are larger than expected. Devising unambiguous questions for complexity of reading material is more difficult than for math and the item for professional journals may include over-reporting relative to what an external observer might consider a professional journal, but this cannot be confirmed without more intensive study. In addition, in the first wave of STAMP it was anticipated that so few people would read books as a regular part of their jobs that the question asked whether respondents ever read work-related books, which probably led to over-reporting as well. The second wave collected additional information on the number of books usually read to distinguish light from heavy readers.

In general, the results for reading suggest significant bifurcation in demands among U.S. jobs. Nearly $20 \%$ of jobs have quite basic levels of reading demand, in which 
the longest document is no more than a single page. At the upper end, $40-50 \%$ of jobs appear to require reading books and professional articles, which are relatively complex literacy tasks.

Writing Not surprisingly, far fewer people write than read complex text on their jobs, but the specific numbers are revealing. While almost everyone does some limited form of writing at work, the percentages drop dramatically when it comes to writing text that is even a single page long. A large majority of managers and professionals write text at least a page long $(80 \%)$, but only about $35-55 \%$ of other workers do so. Another break point comes at writing text that is at least five pages long. Nearly half of managers and professionals write documents that are at least five pages long, but only about $10 \%$ of other workers do so. ${ }^{7}$ Far fewer workers regardless of occupation group write text such as articles of various kinds or books.

While effective communication skills are undoubtedly useful in most jobs, overall, it appears that the vast majority of U.S. jobs require non-college levels of writing skills.

Documents It is well-known in literacy research that workplace reading materials often differ from those found in academic environments (Sticht 1975; Mosenthal and Kirsch 1998). For example, many jobs involve the use of invoices, forms, and contracts, rather than running narrative text, like reports, articles, and books. For this reason the predecessors of the OECD's Survey of Adult Skills, such as the National Adult Literacy Survey (NALS) in the U.S. and the International Adult Literacy Survey (IALS), treated document literacy as a separate dimension, distinct from prose and quantitative literacy. As Table 2 indicates, over two-thirds of all U.S. wage and salary workers use forms as a regular part of their jobs.

However, most people consider the forms they use to be relatively simple. Workers were asked to rate the complexity of the forms they used on a scale of zero to ten, with the examples of a time sheet and a long legal contract anchoring the lowest and highest ends of the scale. For Table 2, responses were incremented one unit to permit a zero value for the one-third of respondents who used no forms on their jobs. The average form complexity rating on this eleven-

\footnotetext{
${ }^{7}$ Note that the questions refer to the length of texts, not the total amount of writing performed on the job. It is quite possible that over the course of a week or more a worker might write many notes that are several lines long that together add up to a page or even five page's worth of text. However, the questions were worded to exclude this possibility because these kinds of texts are assumed to be less complex than documents with 1 or 5 pages of running text, and repetitive performance of simple writing should not be confused with more complex writing demands.
}

point scale was 3.16 , or 2.87 if the scale were renormalized to ten points.

Accounting for the use of forms does provide more complete coverage of the literacy tasks people perform on their jobs and may capture important distinctions among workers whose jobs involve very low levels of more formal reading and writing. However, for most people, it does not appear that forms constitute a very demanding kind of literacy task on their jobs. Indeed, further research in recent years indicated that document literacy did not constitute a robust, distinct factor, and fewer items for this form of literacy were used for the Survey of Adult Skills and combined with results on prose items for a general literacy scale score (OECD 2012).

Summary General academic skills are a major focus of concern over skill shortages, the rise of an informationcentred economy, and the performance of the educational system. However, the absolute levels of such skills that are required on most jobs do not appear to be very high, with the possible exception of reading, particularly for jobs other than managerial and professional occupations.

Qualifying this portrait somewhat, it must be noted that higher levels of reading, writing, and math may be a necessary foundation for acquiring more occupationally-specific knowledge, which could not be captured by STAMP. Reading tasks, in particular, are critical for the initial acquisition of job-specific skills and for continuing participation in formal training off the job. Workers may need more advanced skills than they use on their jobs in order to gain the knowledge and skills necessary to perform their jobs. If this is the case, workers may need higher academic skills than can be inferred from these figures alone because they are a reserve capacity that is used mostly off the job itself. This is likely to be true particularly in the case of reading, which is necessary to understand written training material for all occupations, whereas latent writing and math capacities are much less likely to be activated during training.

Broadening the focus, it is also true that a solid general education helps widen the range of occupational choices open to students who have not settled on a career even if some of the skills and knowledge is never used in their work lives and atrophies across the life course.

Likewise, in terms of broader education policy implications, the preceding does not address other important functions of education, such as its effects on personal socioemotional and general cognitive development, appreciation of knowledge in general, effective citizenship, and broader social cohesion. As only one example, the ability to perform simple numerical calculations has been shown to predict delinquencies and defaults on recent subprime mortgages net of controls, probably reflecting differences in the ability to manage other aspects of personal finance such as 
Table 3 Distributions of Educational Attainment and Required Education, and Rates of Mismatch

\begin{tabular}{llll}
\hline Aggregate distribution & Attained & Required & Attained-Required \\
$<$ High school & 9.0 & 7.6 & 1.4 \\
High school & 25.9 & 42.6 & -16.7 \\
High school + vocational & 5.7 & 6.3 & -0.6 \\
<Bachelors & 29.1 & 16.5 & 12.6 \\
Bachelors & 20.0 & 20.8 & -0.8 \\
Graduate & 10.3 & 6.3 & 4.0 \\
& & & \\
Individual matches & All & $30 \leq$ Age $\leq 59$ & \\
Under-educated & 13.2 & 14.1 & \\
Matched & 55.3 & 57.4 & \\
Over-educated & 31.5 & 28.6 & \\
\hline
\end{tabular}

Note: All figures are percentages spending and savings (Gerardi et al. 2010). Clearly, education has important effects on personal life outside work, as well as on participation in the broader society (Pascarella and Terenzini 2005). Nor does the STAMP portrait of work today foreclose the possibility that if jobs were more enriched in terms of general literacy skills in the future there might be gains to productivity.

Nevertheless, looking at work as it is performed now in the United States in the context of recent debates over education, the knowledge economy, and workforce skills, it is the relatively modest level of basic literacy and numeracy skills exercised as a regular part of most jobs that is notable. The current U.S. standard of living results from jobs performed as portrayed above.

\subsection{Problem solving}

In addition to literacy and numeracy skills, which can be specified relatively easily, another key job requirement is general cognitive skills. Whether they should be considered an academic skill is arguable. Clearly, general cognitive skills are developed partly through schooling, as well as general maturation, but mostly they are a by-product of subject-specific learning and not a distinct focus of organized instruction. Indeed, these kinds of general reasoning or "thinking" skills are difficult to define with much concreteness in both academic and job contexts because of their very generality, despite the ubiquity of calls to build more "critical thinking skills" into academic curricula and employers' expressed desires for better problem-solving skills from their workers. General thinking skills are important because they are implicated in almost every work situation, but they are difficult to pin down in a short compass because they include so many diverse situations and behaviours.

To measure the general thinking skills required on the job, STAMP asked respondents the frequency with which they had to solve easy problems, defined as requiring little time and assistance from others, and hard problems, defined as those requiring a great deal of work to solve $(1=$ never, $2=$ rarely, $3=$ sometimes, $4=$ often).

While nearly two-thirds said they had to solve easy problems often, only $22 \%$ often confronted hard problems on their jobs and another $45 \%$ sometimes had to do so. Onethird of U.S. workers said they rarely or never had to solve hard problems on their jobs. The frequency of hard problems did not vary greatly by broad occupation, but was moderately to highly correlated with the level of formal education required by jobs (0.45). While further analyses in conjunction with the other cognitive skill measures will pursue this topic in greater depth, these figures give some indication that the U.S. job structure retains a large segment of jobs that are relatively undemanding in terms of general cognitive requirements, as well as school skills.

\subsection{Required education}

The level of education required to perform a job, as distinct from the job-holder's personal educational attainment, is a final measure of general human capital requirements in STAMP.

Required education and the other cognitive skill measures are mutually complementary, as each provides information absent in the other. The questions on reading, writing, math, and problem solving tasks cover much of the general literacy and cognitive skills domain but they are not exhaustive, whereas required education is an omnibus measure that captures all education-related cognitive skills but lacks specificity. The literacy tasks elaborate the ways in which education is used on the job and potentially help explain why education has such large effects on wages and occupational attainment, while required education fills the gaps that remain in those batteries.

However, required education is not an entirely clean summary measure of workplace cognitive skill demands because it may reflect other kinds of job demands as well. A job might require a certain level of education because of the attitudes, behavioural habits, motivation levels, inter- 
personal and communication skills, and other kinds of cultural capital that are either produced or signalled by a given education level, quite apart from any cognitive skills not included in the STAMP literacy and problem solving measures.

Nevertheless, a measure of job required education is indispensable because of the prominence of claims that inequality growth in recent decades reflects an imbalance or mismatch between the demand for and supply of skills delivered through education. ${ }^{8}$ Required education also correlates consistently more strongly with workplace literacy tasks, problem solving, and wages than does personal education, indicating it is a better measure of cognitive skill requirements than personal education even if it might also pick up some of the non-cognitive correlates of education that are rewarded in the labour market (Handel 2008). ${ }^{9}$

One way to address the skill shortage claim is by comparing the distributions of required and attained education. The picture is more complicated than the traditional skills shortage message suggests. The top panel of Table 3 shows that despite much talk of the disappearance of low-skill jobs, slightly more than half of all jobs require a high school education or less, while $27 \%$ require a four-year college degree or more. The third column shows that in aggregate terms there is a significant surplus of jobs requiring only a high school education relative to the number of workers with that level of education. There is also a surplus of workers with some college education relative to the number of jobs requiring that level of education. The shares of workers and jobs at the BA level are in balance in aggregate terms, though not at the individual level (see below). Finally, while there is much discussion of the need for a highly educated workforce, $10 \%$ of workers reports having more than a four-year degree but only $6 \%$ reports that their job requires that much education.

This last point is significant because the expectation is that if there is any bias in responses it is in the direction of self-enhancement; few people are motivated to report holding jobs below their level of education. One possible explanation for these results is that respondents themselves recognize some kind of credentialism exists on their job. An advanced degree may be required for job entry or promotion but not for performing the work itself, which may be the case for some kinds of masters degrees. There may also be mismatches between supply and demand that force people to work outside the field in which they studied or to remain under-utilized within it. However, neither of these

\footnotetext{
8 These debates and available evidence are reviewed in Handel (2003b, 2005b).

${ }_{9}$ In general, correlations between cognitive job tasks and required education are 0.10 higher than the corresponding correlations between those tasks and workers' personal education.
}

explanations nor the basic result itself is consistent with the dominant skills shortage thesis, which would not predict an over-supply of highly educated workers.

The bottom panel of Table 3 calculates rates of (mis) match at the individual level and reveals even higher rates of over-education. Approximately $30 \%$ of the work force is over-educated in the sense that they hold jobs requiring less education than they have attained. One might expect that young workers still searching for career jobs and some older workers nearing retirement or semi-retired might hold jobs below their abilities as a temporary, life-cycle circumstance. In fact, the proportion that is over-educated remains little changed when the sample is restricted to workers aged 30-59. Although a longitudinal perspective might show significant outflows from overeducation within individual careers, these would presumably be offset by inflows into overeducation to produce the cross-sectional results for prime-aged workers observed here.

The greatest source of mismatch are those with some college education, nearly half of whom work in jobs requiring only high school $(42 \%)$ or less than high school (5\%) (not shown). This group accounts for $44 \%$ of the over-educated. Among those with a four-year college degree, nearly a third hold jobs with lower educational requirements. Among those with some graduate education, about one-half work in jobs that they report requires less education (not shown).

It should be noted that what appears to be over-education may represent rough matching that is masked by the coarseness of the education categories. Both persons and jobs within a given education category are heterogeneous. Workers who appear mismatched may be at the lower end of the skill distribution within their education group or working outside of their field of study, and their jobs may be at the upper end of the skill distribution for the (lower) level of education in which the jobs are classified. In this case, the degree of actual skill mismatch may be much smaller than appears, though it should be noted that this is not the explanation for observed mismatch in developing countries participating in the World Bank's STEP survey (Handel et al. 2016).

The group of under-educated workers, with less education than is required for their jobs, is a smaller group than the over-educated $(<15 \%)$. Their status suggests skill deficits. However, some of these people may be at the upper end of the skill distribution within their education group, qualifying them for higher-level jobs, and the jobs may be at the lower end of the skill distribution for jobs with that (higher) level of required education. In addition, work experience may be an alternate route for job qualification for many workers, which is not necessarily evident from information on their educational attainment and their job's educational requirements. 
Table 4 Trends in education required by job 1969-2005 (percentage)

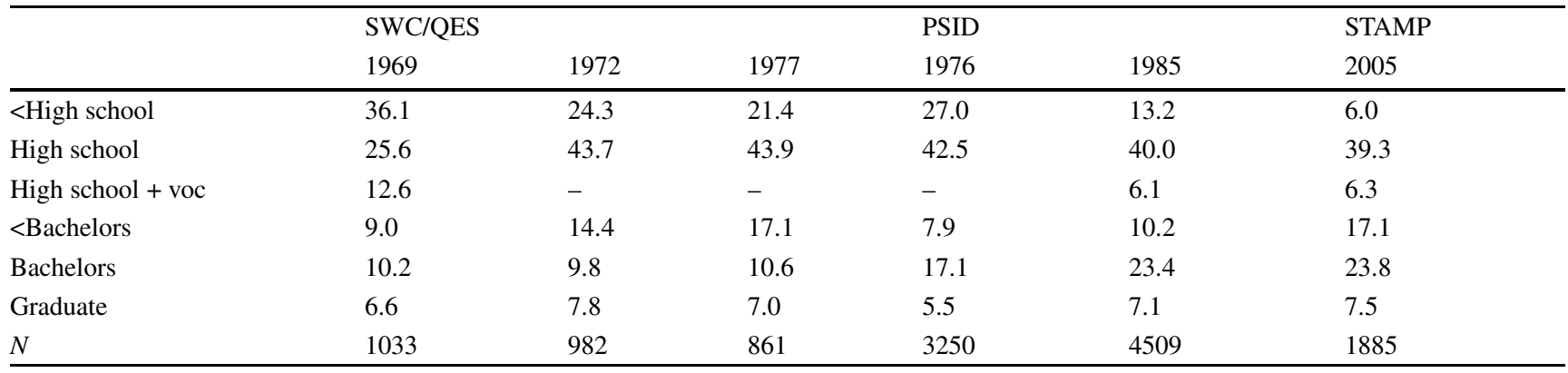

Note: Samples are restricted to workers over 25 working at least $20 \mathrm{~h}$ per week for comparability. All figures are percentages calculated using sampling weights, excluding final row

Sources: Author's tabulations from Survey of Working Conditions (1969), Quality of Employment Surveys (1972, 1977), and Panel Study of Income Dynamics (1976, 1985), Survey of Skills, Technology, and Management Practices (2005)

Some additional insight into the skill profile of U.S. jobs can be gained by comparing the current distribution of job educational requirements to historical figures. To my knowledge, there are only five previous national surveys of the U.S. workforce with comparable data: the three waves of the Quality of Employment Survey (QES) (1969, 1972, 1977) and two waves of the Panel Study of Income Dynamics (PSID) (1976, 1985). Splicing these series together and adding STAMP results gives some rough indication of the pattern of change over 35 years. Although efforts were made to make the samples as consistent as possible and the QES and PSID were both conducted by the same survey research centre, there are always hazards in trying to combine data sets in this way, as will be apparent.

Table 4 shows a sharp decline in the share of jobs requiring less than a high school degree between 1969 and 1985, and a further decline between 1985 and 2005. The proportion of jobs requiring a high school education declined modestly between the 1970s and 1985, and has remained essentially constant since then. Taking the three non-college categories together as a group, it appears that they declined from $74.3 \%$ in 1969 to $59.3 \%$ in 1985 , an annual rate of -0.94 percentage points, and declined further to $51.6 \%$ in 2005 , as the annual rate of decline decelerated to -0.39 percentage points.

Conclusions regarding trends in jobs requiring some college are clouded by inconsistencies between the QES and PSID. The share of jobs requiring a four-year college degree increased in the 1970s and early 1980s, and has remained essentially constant since then. Combining these two groups also suggests a deceleration in the annual growth of jobs requiring college education: 0.90 (1969-1985) vs. 0.37 (1985-2005). Even more striking, the share of jobs requiring post-graduate work has remained roughly constant for the entire period 1969-2005. Although comparing samples across surveys requires caution, there is little support for the idea that skill upgrading has proceeded at an especially rapid pace in recent years.

\subsection{Specific human capital - experience, learning times, and training}

The final area of cognitive skills demands is job-specific, in contrast to the measures of general cognitive requirements described above. By its very nature, job-specific demands are difficult to measure on a common scale in a general labour force survey. They are measured partly by the $6.3 \%$ of workers who said the education required for their job included vocational education (Table 4). In addition, STAMP measured specific human capital outside of education as required years of prior experience in related jobs, learning time on the current job, and employer-provided training in the prior three years. Although increasing returns to experience was one dimension of rising wage inequality in the U.S., and greater firm-provided training might be one expected aspect of rising job skill requirements, in practice neither has figured prominently in recent research. Indeed, one study using one of the few consistent time series data on training in the U.S. found it did not contribute to rising inequality (Constantine and Neumark 1996). In the STAMP paradigm, these measures capture the diversity of innumerable specific job requirements in comparable terms as scalars using time spent as the common unit.

Table 5 shows that the median length of required prior experience in related jobs is 1.5 years (mean = 2.7 years) and the median time required to learn one's job is 3.5 months (mean $=12.5$ months). These figures do not appear very large on their face, but evaluating their magnitudes is difficult in the absence of historical data or some other reference point. In theory, prior experience and on-the-job learning may substitute for general human capital requirements, but the correlations between educational requirements and both required prior experience $(0.35)$ and $(\mathrm{ln})$ learning times $(0.41)$ indicate they are more often complements than substitutes in practice.

About $45 \%$ of workers received formal classroom training provided or paid for by their employers in the previ- 
Table 5 Specific human capital - required prior experience in related jobs, job learning times, and formal training provided by employers

\begin{tabular}{ll}
\hline & Percentage \\
\hline Prior experience & 21.8 \\
None & 14.8 \\
$<1$ year & 27.1 \\
1-2 years & 20.3 \\
3-5 years & 15.9 \\
$>5$ years & $2.7(1.5)$ \\
Mean (median) in years & \\
Job learning times & 5.3 \\
$<1$ week & 21.6 \\
1-4 weeks & 27.3 \\
1-6 months & 23.9 \\
6-12 months & 21.8 \\
$>1$ year & $12.5(3.5)$ \\
Mean (median) in months & \\
Classroom training & \\
Any & 44.0 \\
Read, write, math & 11.8 \\
Customer service & 17.1 \\
Management & 19.4 \\
Communication & 21.7 \\
Quality control & 10.3 \\
Other technical & 25.8 \\
\hline
\end{tabular}

${ }^{\mathrm{a}}$ Formal classroom training paid or provided by employers in the previous three years

ous three years. Consistent with previous research, training tended to be associated with jobs that already required more education $(r=0.31)$ and longer learning times $(r=0.25)$, but is more weakly associated with related job experience requirements $(\mathrm{r}=0.12)$, perhaps because they are sometimes functional substitutes. As might be expected, more occupationally-specific kinds of training, such as customer service and quality training, were not associated with educational requirements. It is not clear that there are truly comparable data from earlier periods to perform trend analyses, but these figures provide a benchmark for any future work. One notable finding is that despite all of the discussion of the emphasis on quality control, this was the least common form of employer-provided training, undertaken by only $10 \%$ of the workforce in the previous three years.

\subsection{Interpersonal and physical job demands}

Interpersonal demands The shift from a manufacturing to a service economy, as well as the increased use of teams, has focused attention on the interpersonal demands of work (e.g. Reich 1991). However, some research suggests that interpersonal skills are not rewarded in the labour market in the form of higher wages (Glomb et al. 2004), rais- ing the possibility that they are marginal to current debates on inequality trends. This may also reflect difficulties in measuring levels of interpersonal skill demands, not least because the domain is very heterogeneous and poorly defined (Handel 2008). Pretests for STAMP also confirmed suspicions that this domain is subject to substantial yeasaying bias among respondents; people are prone to affirm the importance of "people skills" regardless of differences in the content of their jobs.

Indeed, Table 6 indicates that relatively high proportions of workers responded positively to several items. The most notable exception is the question on whether respondents gave formal presentations lasting at least 15 minutes as a regular part of their jobs. Nearly $60 \%$ of managers and professionals give presentations, but only 10-20\% of workers in the other occupational groups do so. As would be expected, blue-collar workers are also much less likely to have contact with the public than other groups.

Physical demands Recent discussions regarding the labour market prospects of less educated workers argue that cognitive and interpersonal job requirements are generally high, as also argued by a longstanding theme in the sociology of post-industrialism. A concomitant argument is that physical job demands are relatively low given the declining share of blue-collar manufacturing jobs and the increasing use of advanced technology within remaining manual jobs (Bell 1973; Zuboff 1988; Reich 1991).

Table 6 confirms expectations that blue-collar jobs require more standing, heavy lifting, eye-hand coordination, and overall physical demands than white-collar jobs, but service jobs are not far behind on many measures. Although there is little comparable historical data on physical demands, these tasks are concentrated in occupations and industries that have been declining over time, which is consistent with post-industrial and related theories of job trends.

\subsection{Conclusion}

The preceding clarifies the nature of skills required by American jobs and casts some doubt on any easy generalization regarding the high skill content of American jobs. While reading requirements are in some cases surprisingly high, requirements for math, writing, and some high-level interpersonal skills are relatively low, and problem-solving requirements are generally moderate. Half of the jobs are described by workers as requiring no more than a high school degree, and over $30 \%$ of workers report their jobs require less education than they have attained personally. Also casting doubt on the notion that less skilled jobs are effectively disappearing are other developments, such as the fall in unemployment in the booming late 1990s to levels 
Table 6 Interpersonal and physical job demands

\begin{tabular}{|c|c|c|c|c|c|c|}
\hline & All & Upper WC & Low WC & Upper BC & Low BC & Service \\
\hline \multicolumn{7}{|l|}{ Interpersonal $(\alpha=0.72)$} \\
\hline Give information & 92 & 98 & 94 & 86 & 85 & 81 \\
\hline Counsel people & 37 & 50 & 28 & 28 & 26 & 38 \\
\hline Deal w/tense situations & 60 & 65 & 60 & 51 & 49 & 65 \\
\hline Teach or train people & 75 & 86 & 69 & 75 & 67 & 67 \\
\hline Interview people & 18 & 30 & 16 & 7 & 6 & 9 \\
\hline Presentations $>15 \mathrm{~min}$ & 32 & 57 & 20 & 17 & 11 & 17 \\
\hline Public contact ${ }^{\mathrm{a}}$ & 3.04 & 3.69 & 3.45 & 1.94 & 1.60 & 2.79 \\
\hline Importance level $^{\mathrm{b}}$ & 7.40 & 8.79 & 8.31 & 5.01 & 4.21 & 6.88 \\
\hline \multicolumn{7}{|l|}{ Physical $(\alpha=0.79)$} \\
\hline Stand $\geq 2 \mathrm{~h}$ & 67 & 52 & 58 & 90 & 80 & 90 \\
\hline $\mathrm{Lift} /$ pull $\geq 50 \mathrm{lbs}$ & 36 & 19 & 27 & 73 & 60 & 48 \\
\hline Good coordination & 57 & 43 & 42 & 89 & 78 & 75 \\
\hline Physical demands ${ }^{c}$ & 4.59 & 3.46 & 3.67 & 6.67 & 5.98 & 6.23 \\
\hline
\end{tabular}

Note: Figures are percentages responding positively $(1=$ yes $)$ unless noted

${ }^{a}$ Frequency of contact with people other than co-workers, such as customers, clients, students, or the public lasting 15 min or more $(0=$ none, $1=$ $<1$ per week, $2=1$ per week, $3=$ few times per week, $4=1$ per day, $5=>1$ per day)

bSelf-rated importance of working well with customers, clients, students, or the public on respondent's job (0-11)

${ }^{\mathrm{c}} \mathrm{Self}-$ rated physical demands of job $(0=$ not all physically demanding, $10=$ extremely physically demanding $)$

not seen since the late 1960s and the absorption of large numbers of former welfare recipients and unskilled immigrants during and after this period. There appears to be plenty of less skilled jobs remaining in the U.S. economy, and a significant number still require substantial physical labour. Only further monitoring of future trends will determine whether this situation persists and the rate of any change from current levels.

\section{Technology use}

\subsection{Computers}

No development has received more attention in the labour economics literature on inequality growth than the spread of computer use at work. The dominant explanation for inequality growth among labour economists across the developed world is that exogenous, skill-biased technological change combined with an inadequate supply response caused the growth in demand for human capital to outpace the growth in supply, raising the returns to education.

The exact causal argument relating computers to skills and wages remains somewhat unsettled but several pathways have been proposed and investigated. The wage premium for computer use has been seen as evidence that computer hardware and software are complex and require a significant training investment, for which users are compensated in the labour market (Krueger 1993; Borghans and ter Weel 2004; Dickerson and Green 2004; Dolton and Makepeace 2004). Others argue that computers may not be complex or difficult to learn in themselves, but may require more of the general cognitive skills discussed above and additional skills entailed by complementary employee involvement practices (Levy and Murnane 1996; Autor et al. 2002; Bresnahan et al. 2002; Shaw 2002, Spitz-Oener 2006). Technology may also alter the occupational composition of the workforce without altering the task content of jobs themselves, as in the automation and elimination of manual jobs.

Employee involvement and technological displacement are discussed in subsequent sections, while the effects of computers on literacy and other cognitive skills is a complex modelling issue to be addressed in a subsequent paper. ${ }^{10}$ The aim here is simply to measure the incidence of various kinds of computer-related tasks and the likely levels of complexity involved in using this software in the narrow sense, i.e., the cognitive complexity of computer technology itself.

STAMP asked twenty-seven questions related to computer use, particular applications, functions, and levels of task complexity, as well as self-reported user competence in using computers. About $70 \%$ of STAMP respondents reported using a computer at work at least a few times per week. Table 7 presents a selection of further results, most of which are calculated over the total sample (users and non-users). An unexpectedly large proportion of clerical and sales workers report spending most of their time doing data entry or filling out forms (31\%), which is suggestive

\footnotetext{
${ }^{10}$ For earlier discussions of these issues, see Handel (2003a, 2004, 2007).
} 
Table 7 Computer use

\begin{tabular}{|c|c|c|c|c|c|c|}
\hline & All & Upper WC & Low WC & Upper BC & Low BC & Service \\
\hline 1. Data entry most of time & 14 & 14 & 31 & - & 4 & 3 \\
\hline 2. Spreadsheets & 40 & 64 & 44 & 13 & 18 & 14 \\
\hline 3. Spreadsheet macros, equations & 12 & 21 & 11 & 2 & 6 & 3 \\
\hline 4. Databases & 19 & 32 & 20 & 7 & 7 & 3 \\
\hline 5. SQL database queries & 3 & 8 & 1 & 1 & 1 & 1 \\
\hline 6. CAD & 7 & 10 & 5 & 5 & 6 & 2 \\
\hline 7. Science/engineering tasks & 7 & 14 & 3 & 4 & 4 & 2 \\
\hline 8. Programming & 4 & 8 & 2 & 0 & 1 & 1 \\
\hline 9. Special software & 47 & 61 & 59 & 23 & 29 & 24 \\
\hline 10. New software in last 3 years $^{\mathrm{a}}$ & 16 & 24 & 16 & 11 & 12 & 6 \\
\hline 11. No. of applications $(\max =15)$ & 4.02 & 6.06 & 4.68 & 1.68 & 1.91 & 1.41 \\
\hline 12. Computer skill level ${ }^{\mathrm{b}}$ & 4.21 & 5.91 & 5.06 & 1.95 & 2.43 & 1.77 \\
\hline 13. Inadequate skills (users only) & 23 & 26 & 18 & 30 & 23 & 22 \\
\hline 14. Affected pay/promotion & 8 & 3 & 5 & 10 & 18 & 13 \\
\hline
\end{tabular}

Note: All statistics are percentages except lines 11 and 12. All calculation use full sample except lines 13 and 14

$S Q L$ structured query language, $C A D$ computer-aided design

aRespondents were asked whether in the last three years they had to learn any new computer programs or functions that took more than a week to learn

${ }^{\mathrm{b}}$ Self-rated complexity of computer skills used on job $(0=$ no computer use, $1=$ very basic, $11=$ very complex $)$

of deskilling, but this is very atypical for the workforce as a whole. A large proportion of all workers use spreadsheets $(40 \%)$, but a much smaller group uses more complex functions like macros and equations (12\%); presumably, spreadsheets are used simply as electronic ledgers by most workers. Similarly, while nearly $20 \%$ use databases, only $3 \%$ program or write queries using the computer language SQL. Between 5 and $10 \%$ of the workforce uses computers for CAD, high-level quantitative analysis (scientific or engineering calculations, simulations, statistics), or programming using a computer language such as $\mathrm{C}++$, Java, Perl, and Visual Basic. In general, these tabulations suggest most people use computers for fairly mundane office duties rather than very complex tasks.

At a more summary level, the average number of applications used on the job is four out of the fifteen applications queried, which includes a catchall question on whether the respondent uses a customized or special program found mostly in their specific line of work. Not surprisingly, given that computers are most effective at processing information and assisting white-collar work, managers/professionals and clerical/sales workers use more applications (5-6) than blue-collar and service occupations $(<2)$. Both groups of white collar workers are also more likely to use software applications specific to their line of work $(\sim 60 \%)$ compared to the other occupational groups $(\sim 25 \%)$.

It has become a truism that in the information age nothing is constant except change and workers are engaged in continuous learning in the workplace. However, there are no real estimates of the rate of technological change as it af- fects skill requirements. In fact, relatively few people have had to spend more than one week learning new software within the previous three years $(16 \%)$, though again, there is a slight occupational gradient, as somewhat more upper white collar workers $(24 \%)$ experienced new software introductions in this timeframe.

About one-quarter of computer users report that they do not have all the computer skills needed to do their job well. However, a relatively small proportion of the total workforce (users and non-users), eight percent, report that lack of computer skills has affected their chances of getting a job, promotion, or pay raise, though the figure is somewhat larger for lower blue-collar workers. Individuals seem quite willing to report that their computer skills could use improvement, but these particular shortfalls do not seem to be serious hindrances for most people's career advancement. This is roughly consistent with employers' reports of the level of computer skill deficits they observe, but lack of comparability among data sources prevents great certainty (Teixeira 1998, p. 3). These results are not supportive of the view that a shortage of computer-specific human capital is a prime candidate for explaining widening wage inequality, but this conclusion must be considered tentative in the absence of more detailed analyses.

\subsection{Non-computer technology}

Aside from computers, there is a large class of more traditional mechanical technology associated with skilled and less skilled blue-collar work. This technology has been the subject of conflicting claims that it is the source of 
Table 8 Mechanical and other technology

\begin{tabular}{|c|c|c|c|c|c|c|}
\hline & All & Upper WC & Low WC & Upper BC & Low BC & Service \\
\hline \multicolumn{7}{|l|}{ Machine technology } \\
\hline 1. Heavy Machinery & 20 & 7 & 11 & 65 & 46 & 12 \\
\hline 2. Maintenance & 10 & 3 & 1 & 41 & 21 & 10 \\
\hline 3. Repair & 8 & 3 & 1 & 35 & 16 & 7 \\
\hline 4. Machine set-up & 12 & 4 & 4 & 41 & 29 & 8 \\
\hline 5. Use machine tools & 4 & 1 & 1 & 12 & 14 & 2 \\
\hline 6. Use $N C / C N C$ & 2 & - & - & 3 & 9 & - \\
\hline 7. Program $N C / C N C$ & 1 & - & - & - & 6 & - \\
\hline 8. Operate robots & 1 & - & 1 & 2 & 3 & - \\
\hline 9. Program robots & - & - & - & 1 & 1 & - \\
\hline 10. PLCs & 2 & 1 & - & 6 & 4 & - \\
\hline $11 \mathrm{CPC}$ & 4 & 3 & 2 & 14 & 12 & - \\
\hline 12. Program $C P C$ & 1 & 1 & - & 4 & 3 & - \\
\hline 13. Automated equipment & 5 & 2 & 2 & 9 & 19 & 1 \\
\hline 14. Assembly line & 2 & - & 1 & 5 & 12 & - \\
\hline 15. New machinery in 3 yrs & 10 & 4 & 4 & 32 & 23 & 6 \\
\hline 16. Learning time $>1$ week & 4 & 1 & 2 & 13 & 12 & 1 \\
\hline 17. Mechanical Skill Level ${ }^{\mathrm{a}}$ & 2.50 & 1.73 & 1.38 & 5.97 & 4.55 & 2.12 \\
\hline 18. Electronics Skill $(1=$ yes $)$ & 13 & 12 & 8 & 33 & 15 & 9 \\
\hline
\end{tabular}

Note: All figures are percentages except line 17. Blank cells have rounded values less than $1 \%$

$N C$ numerically-controlled machine tool (1 = yes), CNC computer numerically-controlled machine tool $(1=$ yes $), P L C$ programmable logic controllers $(1=$ yes $), C P C$ computer process control $(1=$ yes $)$

${ }^{\mathrm{a}}$ Mechanical skills: $0=$ very basic, $10=$ very complex

widespread deskilling, on the one hand, and skill upgrading as the result of employee involvement practices and incorporation of programmable microelectronics, on the other. STAMP's questions on the use of heavy machines and industrial equipment tried to capture the different faces of work with non-computer machinery: traditional craft skills (e. g., machine set-up, maintenance, repair), newer hightechnology skills (e. g., programmable automation technology), and deskilled tasks (e. g., machine tending, assembly line work).

Table 8 shows that only $20 \%$ of the work force uses heavy machines and industrial equipment, not surprisingly concentrated among blue-collar workers. How many of these jobs require craft skills, restrict employees to the most deadening kind of deskilled labour, or bring production work into the information age?

Despite claims that employee involvement has led to significant sharing of traditional craft tasks with less skilled blue-collar workers, activities such as routine maintenance, repair, and machine set-up (Table 8 , rows 2-4), remain significantly more common among skilled blue-collar workers.

Likewise, despite the great attention given to machining as a traditional craft and various kinds of modern automation (rows 5-13), few workers in any broad occupational group use machine tools or any kind of automated production equipment on their jobs. It is not necessarily surprising that few production workers use or interface with automated equipment, as the elimination of labour is one goal of automation. Nevertheless, it is important to recognize that most remaining production jobs do not have a high-tech character because they are in contexts in which the introduction of computerized processes has made fewer inroads. By the same token, despite the historic attention given to assembly line work, only $12 \%$ of less skilled blue-collar workers report working under those conditions (row 14). In general, the task content of jobs involving machinery and heavy equipment conform to neither the extreme deskilling nor the optimistic upgrading scenarios.

About a third of skilled blue-collar workers and a quarter of less skilled blue-collar workers started using new equipment or machinery in the previous three years (row 15) and about $12-13 \%$ had to spend more than a week learning the new technology (row 16). Despite all the talk about the speed of change in the information economy compared to the industrial economy, this rate of learning for new machinery and equipment is comparable to that for new software introductions among lower white-collar workers (Table 7, row 10). Only upper white-collar workers experience somewhat higher rates of new technology learning.

All workers were asked the level of mechanical knowledge needed for their jobs and whether they need a good knowledge of electronics, which partly reflects the diffusion of microelectronic technology. Not surprisingly, the average level of required mechanical knowledge was sig- 
Table 9 Employee involvement practices

\begin{tabular}{|c|c|c|c|c|c|c|}
\hline & All & Upper WC & Low WC & Upper BC & Low BC & Service \\
\hline 1. Job rotation & 53 & 43 & 64 & 48 & 60 & 57 \\
\hline 2. Pay for skill & 10 & 6 & 11 & 8 & 16 & 16 \\
\hline 3. TQM/QC & 20 & 22 & 21 & 17 & 19 & 15 \\
\hline 4. Team member ${ }^{\mathrm{a}}$ & 26 & 27 & 21 & 28 & 25 & 26 \\
\hline \multicolumn{7}{|l|}{ Team functions: $(\alpha=0.69)$} \\
\hline 5. Job assignment ${ }^{\mathrm{a}}$ & 20 & 22 & 17 & 26 & 17 & 22 \\
\hline 6. Task scheduling ${ }^{\mathrm{a}}$ & 18 & 21 & 14 & 19 & 15 & 19 \\
\hline 7. Worker scheduling ${ }^{\mathrm{a}}$ & 9 & 7 & 8 & 14 & 10 & 13 \\
\hline 8. Changing methods ${ }^{\mathrm{a}}$ & 18 & 20 & 15 & 22 & 19 & 16 \\
\hline 9. New equipment ${ }^{\mathrm{a}}$ & 18 & 19 & 14 & 25 & 18 & 17 \\
\hline 10. Selecting leader ${ }^{\mathrm{a}}$ & 8 & 10 & 5 & 13 & 8 & 4 \\
\hline 11. Quality ${ }^{\mathrm{a}}$ & 17 & 19 & 13 & 19 & 18 & 13 \\
\hline 12. Cost, productivity ${ }^{\mathrm{a}}$ & 11 & 12 & 11 & 14 & 12 & 9 \\
\hline 13. Cross-communicate ${ }^{a}$ & 20 & 22 & 17 & 21 & 19 & 17 \\
\hline 14. Performance review ${ }^{a}$ & 11 & 11 & 9 & 17 & 10 & 13 \\
\hline 15. \# of team functions ${ }^{\mathrm{a}}$ & 1.41 & 1.49 & 1.21 & 1.81 & 1.44 & 1.26 \\
\hline 16. \# of team functions ${ }^{\mathrm{b}}$ & 5.77 & 5.63 & 5.79 & 6.56 & 5.75 & 5.51 \\
\hline
\end{tabular}

Note: All figures are percentages except lines 15 and 16. Unless noted, all statistics based on full sample. TQM Total Quality Management, $Q C$ quality circle

Cronbach's $\alpha$ for team items calculated on sub-sample of team members only. Team functions (items 5-16) were dichotomized for this table such that $0=$ no involvement and $1=$ team either suggests or decides on its own

${ }^{a}$ Employees in self-reported management positions were ineligible for this item and coded as zero for calculations

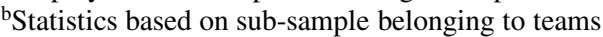

nificantly higher in blue-collar than white-collar occupations. In addition, less than $15 \%$ of the overall workforce requires a good knowledge of electronics, but the figure is significantly higher for skilled blue-collar workers (33\%). Further research is needed to understand the depth of this knowledge. Overall, microelectronic hardware seems not to have affected skill requirements for most jobs, with the possible exception of skilled blue-collar jobs.

\subsection{Employee involvement practices}

A number of researchers have argued that the spread of information technology and more rapidly changing markets have resulted in downward delegation of decision making responsibilities formerly belonging to supervisors and staff in order to shorten decision times and improve quality (Piore and Sabel 1984; Zuboff 1988; Osterman 2000; Bresnahan et al. 2002). These organizational changes known as employee involvement (EI) practices are the third major pillar of recent debates regarding the changing nature of work because they are assumed to raise cognitive and interpersonal skill requirements (for a review of their wage effects, see Handel and Levine 2004).

Concretely, EI is generally conceived to involve practices like job rotation and cross-training on different jobs to increase task variety and flexibility, pay linked to incremental skills acquisition, and participation in quality improvement initiatives involving analytic techniques and group problem-solving. In its most advanced form, work is organized around self-directed teams that take on numerous supervisory and staff functions.

Table 9 shows that slightly over half of the workforce engages in some kind of job rotation or cross-training, also known as multi-skilling. ${ }^{11}$ The magnitude of learning involved is difficult to evaluate, as it is possible many workers are required to know multiple simple jobs, but it does suggest most jobs require functional flexibility. However, explicit pay-for-skill programs that represent the fullest expression of cross-training practices are relatively uncommon $(10 \%)$. Likewise, only $20 \%$ of the workforce is engaged in a formal quality control program and about one-quarter of all workers belongs to a self-directed work team, suggesting limited penetration of EI principles even after several decades of discussion and advocacy among researchers and management figures (Appelbaum and Batt 1994). The average team performs a little less than six of the ten functions measured in the STAMP survey, but this drops to less than 1.5 tasks if averaged over the entire workforce. Not surprisingly, teams were less likely to perform

\footnotetext{
${ }^{11}$ Cross-training is a familiar term in human resource management and was defined for respondents as learning how to do other people's jobs to be able to fill in for co-workers or help out when there is extra work.
} 
Table 10 Downsizing, outsourcing, technological displacement

\begin{tabular}{|c|c|c|c|c|c|c|}
\hline & All & Upper WC & Low WC & Upper BC & Low BC & Service \\
\hline \multicolumn{7}{|l|}{ Employment change } \\
\hline Lot less & 6 & 6 & 4 & 8 & 12 & 3 \\
\hline A little less & 12 & 12 & 14 & 14 & 10 & 9 \\
\hline About same & 50 & 48 & 47 & 52 & 47 & 60 \\
\hline More & 33 & 35 & 35 & 25 & 12 & 29 \\
\hline Permanent layoffs & 8 & 7 & 7 & 7 & 16 & 5 \\
\hline Outsourcing & 4 & 3 & 3 & 5 & 13 & 2 \\
\hline Personally laid off & 10 & 7 & 10 & 15 & 16 & 10 \\
\hline Replaced by machine & - & - & - & - & 1 & 1 \\
\hline Ever on strike & 3 & 2 & 2 & 8 & 7 & 2 \\
\hline
\end{tabular}

Note: All figures are percentages. Cells with (-) have rounded values less than $1 \%$

highly consequential functions usually reserved for management, such as choosing their own leader and conducting peer performance reviews. More surprisingly, a relatively small proportion of teams monitored costs, productivity, and waste, which are supposedly teams' raison d'être because they push problem identification and solution to frontline workers.

The figures in Table 9 are the first statistics giving incidence rates for EI practices in the U.S. based on a nationally representative sample of workers. ${ }^{12}$ They suggest that even after many years of widespread discussion, incorporation into human resource management texts, and efforts at diffusion, employee involvement practices are restricted to a distinct minority of workers. Their effects on skill demand are likely to be limited simply by the modest numbers of workers affected, although their impact on skills and wages among affected workers requires further analysis.

\subsection{Downsizing, outsourcing, and technological displacement}

Finally, the lean and mean perspective points to various developments that some researchers believe have lowered the quality of jobs. Table 10 shows that $18 \%$ of all workers reported their workplaces downsized in the previous three years and $8 \%$ said the process was accompanied by significant numbers of permanent layoffs; the figures are higher for lower blue-collar workers. Overall, $10 \%$ of workers were themselves laid off in the previous three years and about $15 \%$ of both upper and lower blue-collar workers were laid off. These figures precede the recent recession.

Despite great concerns over outsourcing, relatively few people say their workplace transferred work out to other places in the previous three years $(4 \%)$, but the rate for

12 A small number of establishment surveys exist but they have a minimum size threshold (e. g., $>25$ employees) and sometimes other limitations that prevent clean estimates of workforce-level incidence rates. lower blue-collar workers is higher than for other groups (13\%), consistent with expectation. Given the nature of managerial decision making, these estimates from employees are likely to be lower bounds, but at this point there are no other estimates of outsourcing for the overall workforce.

Technological substitution plays an important role in theories of skill-biased technological change, and fears of technological displacement are even older (Woirol 1996; Bix 2000). Strikingly, nearly imperceptible proportions of the workforce report being laid off because a machine or computer replaced them. These worker reports are similar in magnitude to the employer reports on technology as a cause of layoffs that are collected by the U.S. Department of Labor's Mass Layoffs Statistics program (U.S. Department of Labor. Bureau of Labor Statistics 2008, p. 13).

Although technology may be reducing labour requirements through attrition or establishment births and deaths, the classic image of displacement operating through the direct replacement of workers with machines, well-known from histories of the early textile industry and recent decades' experiences in newspaper publishing, seems a very minor part of the overall employment picture (see also Fernandez 2001; Handel 2003a).

While the magnitude of employment effects due to trade and outsourcing have been debated vigorously - and they may well be less important than exchange rates or macro forces - technology may play an even smaller role in job loss processes.

\subsection{Conclusion}

There has been much discussion of the high and rising level of skill demand as information and communication technology becomes pervasive and talk of participatory work reform rose in prominence. Diffuse claims are easy to make in the absence of direct measures, but eventually knowledge can progress only through the collection of better data on the task content of jobs. The preceding begins to pro- 
vide a baseline picture of the skill requirements and related characteristics of U.S. jobs. There is a significant minority of jobs that conform to the common view that the U.S. has a knowledge economy, but for most jobs education requirements and academic skill demands are low to moderate, with the partial exception of reading demands. Large numbers of workers report personal educational levels that exceed those required by their job. More specific forms of human capital such as prior job experience, on-the-job learning, and, to a lesser extent, employer-provided formal training also contribute significantly to job cognitive skill requirements, but the duration and incidence do not seem great and it is difficult to draw conclusions about the particular kinds of skills involved given the diversity of jobs in advanced economies.

Information technology is used widely, but generally at low to moderate levels of complexity. Few people have to spend much time learning new software over a three-year period and few perceive a lack of ICT skills to be a significant barrier to their advancement in the labour market. Very few jobs involve working with automated and programmable heavy machinery, and even fewer workers perceive technology made them redundant in the recent past. Participatory management practices are not widely diffused. Only a small minority perceive outsourcing to have been responsible for any recent job cuts in their workplace.

The dominant impression from this portrait is that with some exceptions, the American workplace has not entered a radically new era but is likely in the process of a more gradual, long-term process of skill upgrading. If there are sharp changes in earnings inequality they are likely to be only loosely coupled to this process, but only a sufficiently long time series will be able to test this inference. This does not rule out the possibility that individuals and the economy might benefit if policies attempted to stimulate more rapid rates of change on both the worker and employer sides of the equation. Nor does the preceding speak to the situation of specific groups, such as those with very low skills and members of disadvantaged groups, who may have severe problems finding employment at living wages even at prevailing levels of job skill requirements. However, large claims regarding the knowledge intensity of current jobs need to be benchmarked against evidence from direct measures of job content that presents a more modest picture overall.

Funding This work was supported by the National Science Foundation (grant number IIS-0326343), the Russell Sage Foundation, and the Wisconsin Alumni Research Fund.

Open Access This article is distributed under the terms of the Creative Commons Attribution 4.0 International License (http:// creativecommons.org/licenses/by/4.0/), which permits unrestricted use, distribution, and reproduction in any medium, provided you give appropriate credit to the original author(s) and the source, provide a link to the Creative Commons license, and indicate if changes were made. 


\section{Appendix}

Table 11 Selected STAMP question text

\section{Mathematics}

The next questions are about using numbers and math on your job, including any math you do with computers or calculators. At your job, do you:

1. use math or numbers in any way (incl. measure or weigh things, count things, work with money)

2. use addition or subtraction

3. use multiplication or division

4. do math using fractions, decimals, or percentages

5. use simple algebra to solve for unknown values

6. use more advanced algebra to solve complex equations

7. use geometry or trigonometry

8. use probability and statistics, such as correlations and regressions

9. use calculus or other advanced mathematics

\section{Reading}

These questions are about different kinds of things you might have to read as a regular part of your job, including anything you might have to read on the computer as well as what you read on paper. As part of your job, do you read:

1. Anything at work, even very short notes or instructions

2. Anything at least one page long, including notes, memos, reports, or letters

3. Anything at least 5 pages long

4. Articles or reports in trade magazines, newsletters, or newspapers

5. Articles in scholarly, scientific publications, or professional journals

6. Instruction manuals or other reference materials

7. Work-related books

8. Bills or invoices

Interpersonal job requirements

The next questions are about working with people. As part of your job, do you:

1. ... give people information or advice?

2. ... counsel people or help them with their personal problems?

3. ... regularly have to deal with people in difficult or tense situations, such as people who are hostile, angry, or upset?

4. ... have to teach or train people?

5. ... regularly interview people, for example people applying for loans, government benefits, jobs, or other things?

6. ... give formal presentations lasting at least $15 \mathrm{~min}$ ?

7. ... have any contact with people other than co-workers, for example with customers, clients, students, or the public?

8. Do you ever spend at least 15 min talking with someone who is not a co-worker?

9. (If yes) In a usual week, about how often do you talk to someone like that for a period of at least 15 min ( $>$ once a day, about once a day, a few times a week, about once a week, less often than that)?

10. Using any number from 0 to 10 where 0 is not important at all and 10 is extremely important, what number would you use to rate how important it is to your job to work well with customers, clients, students, or the public?

Physical demands

Now I'd like you to think about the kinds of physical activity you have to do as a regular part of your job. At your job, do you:

1. ... have to stand or walk for at least $2 \mathrm{~h}$ during your work day?

2.... regularly have to lift or pull anything weighing at least 50 pounds?

3. ... have to perform tasks that require very good hand-eye coordination or an especially steady hand?

4. Using any number from 0 to 10 where 0 is not at all physically demanding and 10 is extremely physically demanding, what number would you use to rate how physically demanding your job is? 


\section{References}

Appelbaum, E., Batt, R.: The new american workplace. ILR Press, Ithaca (1994)

Appelbaum, E., Bailey, T., Berg, P., Kalleberg, A.L.: Manufacturing advantage: why high-performance work systems pay off. ILR Press, Ithaca (2000)

Attewell, P.: What is skill? Work Occup 17, 422-447 (1990)

Autor, D.H., Lawrence, F.K., Krueger, A.B.: Computing inequality: have computers changed the labor market? Q J Econ 113, 1169-1213 (1998)

Autor, D.H., Levy, F., Murnane, R.J.: Upstairs, downstairs: computers and skills on two floors of a large bank. Ind Labor Relat Rev 55, 432-447 (2002)

Bell, D.: The coming of post-industrial society: a venture in social forecasting. Basic Books, New York (1973)

Bix, A.S.: Inventing ourselves out of a job? America's debate over technological unemployment, 1929-1981. Johns Hopkins University Press, Baltimore (2000)

Borghans, L., ter Weel, B.: Are computer skills the new basic skills? The returns to computer, writing and math skills in britain. Labour Econ 11, 85-98 (2004)

Bresnahan, T.F., Brynjolfsson, E., Hitt, L.M.: Information technology, workplace organization, and the demand for skilled labor: firmlevel evidence. Q J Econ 17, 339-376 (2002)

Cain, P.S., Treiman, D.J.: The dictionary of occupational titles as a source of occupational data. Am Sociol Rev 46, 253-278 (1981)

Constantine, J., Neumark, D.: Training and the growth of wage inequality. Ind Relat (Berkeley) 35, 491-510 (1996)

Cook, J.D., Hepworth, S.J., Wall, T.D., Warr, B.: The experience of work: a compendium and review of 249 measures and their use. Academic Press, New York (1981)

Cully, M., Woodland, S., O’Reilly, A., Dix, G.: Britain at work. Routledge, New York (1999)

Danziger, S., Gottschalk, P.: America unequal. Harvard University Press, Cambridge (1995)

Darrah, C.: Skill requirements at work: rhetoric versus reality. Work Occup 21, 64-84 (1994)

Dickerson, A., Green, F.: The growth and valuation of computing and other generic skills. Oxf Econ Pap 56, 371-406 (2004)

Dolton, P., Makepeace, G.: Computer use and earnings in Britain. Econ J 114, C117-C129 (2004)

Felstead, A., Gallie, D., Green, F., Zhou, Y.: "Work Skills in Britain 1986 to 2006. ESRC, Center on Skills, Knowledge, and Organisational Performance, Swindon, Oxford (2007)

Fernandez, R.M.: Skill-biased technological change and wage inequality: evidence from a plant retooling. Am J Sociol 107, 273-320 (2001)

Gerardi, K., Goette, L., Meier, S.: Financial literacy and subprime mortgage delinquency: evidence from a survey matched to administrative data. Working Paper 2010-10. Federal Reserve Bank of Atlanta, Atlanta (2010)

Gerhart, B.: Sources of variance in incumbent perceptions of job complexity. J Appl Psychol 73, 154-162 (1987)

Glick, W.H., Douglas Jenkins Jr., G., Gupta, N.: Method versus substance: how strong are underlying relationships between job characteristics and attitudinal outcomes? Acad Manag Rev 29, 441-464 (1986)

Glomb, T.M., Kammeyer-Mueller, J.D., Rotundo, M.: Emotional labor demands and compensating wage differentials. J Appl Psychol 89, 700-714 (2004)

Graham, L.: Inside a japanese transplant: a critical perspective. Work Occup 20, 147-173 (1993)

Green, F.: Demanding work: the paradox of job quality in the affluent economy. Princeton University Press, Princeton (2006)

Green, F., James, D.: Assessing skills and autonomy: the job holder versus the line manager. Hum Resour Manag J 13, 63-77 (2003)
Green, F., Felstead, A., Gallie, D.: Skills and work organisation in Britain: a quarter century of change. J Labour Mark Res (2016). doi:10.1007/s12651-016-0197-x

Handel, M.J. 2000. Models of Economic Organization and the New Inequality in the United States. Unpublished doctoral dissertation, Sociology Department, Harvard University.

Handel, M.J.: Implications of information technology for employment, skills, and wages: a review of recent research. SRI International, Arlington (2003a)

Handel, M.J.: Skills mismatch in the labor market. Annu Rev Sociol 29, 135-165 (2003b)

Handel, M.J.: Implications of information technology for employment, skills, and wages: findings from sectoral and case study research. SRI International, Arlington (2004)

Handel, M.J.: Trends in perceived job quality, 1989-1998. Work Occup 32, 66-94 (2005a)

Handel, M.J.: Worker skills and job requirements is there a mismatch? Economic Policy Institute, Washington, DC (2005b)

Handel, M.J.: The effect of participative work systems on employee earnings. Res Sociol Work 16, 55-84 (2006)

Handel, M.J.: Computers and the wage structure. Res Labor Econ 26, 155-196 (2007)

Handel, M.J.: Measuring job content: skills, technology, and management practices. Institute for Research on Poverty Discussion Paper, vol. 1357-08. University of Wisconsin, Madison (2008)

Handel, M.J.: Measuring job content: skills, technology, and management practices. In: Buchanan, J., Finegold, D., Mayhew, K., Warhurst, C. (eds.) Oxford Handbook of Skills and Training. Oxford University Press, Oxford (2016)

Handel, M.J., David Levine, I.: The effects of new work practices on workers. Ind Relat (Berkeley) 43, 1-43 (2004)

Handel, M.J., Valerio, A., Sánchez Puerta, M.L.: Accounting for education mismatch in developing countries: measurement, magnitudes, and explanations. World Bank, Washington, DC (2016)

Harrison, B.: Lean and mean: the changing landscape of corporate power in the age of flexibility. Basic Books, New York (1994)

Harrison, B., Bluestone, B.: The great U-turn: corporate restructuring and the polarizing of America. Basic Books, New York (1988)

Harvey, R.J.: Job analysis. In: Dunnette, M.D., Leaetta Hough, M. (eds.) Handbook of industrial and organizational psychology, pp. 71-163. Consulting Psychologists Press, Palo Alto (1991)

Holzer, H.J.: What employers want: job prospects for less educated workers. Russell Sage, New York (1996)

Holzer, H.J., Michael Stoll, A.: Employers and welfare recipients: the effects of welfare reform in the workplace. Public Policy Institute of California, San Francisco (2001)

Katz, L.F., Murphy, K.M.: Changes in relative wages, 1963-1987: supply and demand factors. Q J Econ 107, 35-78 (1992)

Kohn, M.L., Schooler, C.: Work and personality. Ablex, Norwood (1983)

Krueger, A.B.: How computers have changed the wage structure: evidence from microdata, 1984-1989. Q J Econ 108, 33-61 (1993)

Leckie, N., Léonard, A., Turcotte, J., Wallace, D.: Employer and employee perspectives on human resource practices. Statistics Canada, Ottawa (2001)

Levy, F., Murnane, R.J.: With what skills are computers a complement? Am Econ Rev Pap Proc 86, 258-262 (1996)

Lopata, H.Z., Fordham Norr, K., Barnewolt, D., Miller, C.A.: Job complexity as perceived by workers and experts. Work Occup 12, 395-415 (1985)

Manson, T.M., Levine, E.L., Brannick, M.T.: The construct validity of task inventory ratings: a multitrait-multimethod analysis. Hum Perform 13, 1-22 (2000)

Morris, M., Western, B.: Inequality in earnings at the close of the twentieth century. Annu Rev Sociol 25, 623-657 (1999)

Mosenthal, P.B., Kirsch, I.S.: A new measure for assessing document complexity: the PMOSE/IKIRSCH document readability formula. J Adolesc Adult Lit 41, 638-657 (1998) 
Moss, P.I., Tilly, C.: Stories employers tell: race, skill, and hiring in america. Russell Sage, New York (2001)

Murnane, R.J., Levy, F.: Teaching the new basic skills: principles for educating children to thrive in a changing economy. Free Press, New York (1996)

OECD: Literacy, numeracy and problem solving in technology-rich environments: framework for the OECD survey of adult skills. OECD, Paris (2012)

Osterman, P.: Work reorganization in an era of restructuring: trends in diffusion and effects on employee welfare. Ind Labor Relat Rev 53, 179-196 (2000)

Pascarella, E.T., Terenzini, P.T.: How college affects students: a third decade of research. John Wiley and Sons, San Francisco (2005)

Peterson, N.G., Mumford, M.D., Borman, W.C., Jeanneret, R.P., Fleishman, E.A.: An occupational information system for the 21st century: the development of O*NET. American Psychological Association, Washington, DC (1999)

Peterson, N.G., Mumford, M.D., Borman, W.C., Jeanneret, R.P., Fleishman, E.A., Levin, K.Y., Campion, M.A., Mayfield, M.S., Morgeson, F.P., Pearlman, K., Gowing, M.K., Lancaster, A.R., Silver, M.B., Dye, D.M.: Understanding work using the occupational information network $\left(\mathrm{O}^{*} \mathrm{NET}\right)$ : implications for practice and research. Pers Psychol 54, 451-492 (2001)

Piore, M.J., Sabel, C.: The second industrial divide. Basic Books, New York (1984)

Quinn, R.P., Staines, G.L.: The 1977 quality of employment survey: descriptive statistics, with comparison data from the 1969-1970 survey of working conditions and the 1972-1973 quality of employment survey. University of Michigan, Survey Research Center, Ann Arbor (1978)

Reich, R.: The work of nations: preparing ourselves for 21st-century capitalism. A.A. Knopf, New York (1991)

Rohrbach-Schmidt, D., Tiemann, M.: Educational (mis)match and skill utilization in Germany: assessing the role of worker and job characteristics. J Labour Mark Res (2016). doi:10.1007/s12651016-0198-9

Rosenbaum, J., Binder, A.: Do employers really need more educated youth? Sociol Educ 70, 68-85 (1997)

Shaw, K.: By what means does information technology affect employment and wages? The value of IT, HRM practices, and knowledge capital. In: Greenan, N., L'Horty, Y., Mairesse, J. (eds.) Productivity, inequality, and the digital economy. MIT Press, Cambridge (2002)

Smith, V.: New forms of work organization. Annu Rev Sociol 23, 315-339 (1997)

Spector, P.E., Fox, S.: Reducing subjectivity in the assessment of the job environment: development of the factual autonomy scale (FAS). J Organ Behav 24, 417-432 (2003)
Spenner, K.I.: Deciphering prometheus: temporal change in the skill level of work. Am Sociol Rev 48, 824-837 (1983)

Spitz-Oener, A.: Technical change, job tasks, and rising educational demands: looking outside the wage structure. J Labor Econ 24, 235-270 (2006)

Steinberg, R.J.: Social construction of skill: gender, power, and comparable worth. Work Occup 17, 449-482 (1990)

Sticht, T.G. (ed.): Reading for working: a functional literacy anthology. Human Resources Research Organization, Alexandria (1975)

Teixeira, R.: Rural and urban manufacturing workers: similar problems, similar challenges: results of the ERS rural manufacturing survey. Agriculture Information Bulletin Number 736-02. United States Department of Agriculture, Economic Research Service, Washington, D.C. (1998)

U.S. Department of Labor. Bureau of Labor Statistics: Extended mass layoffs in 2006. Report 1004. U.S. Department of Labor. Bureau of Labor Statistics, Washington, DC (2008)

U.S. Department of Labor. Secretary's Commission on Achieving Necessary Skills: What work requires of schools : a SCANS report for America 2000. U.S. Department of Labor, Washington, D.C. (1991)

U.S. National Commission on Excellence in Education: A nation at risk: the imperative for educational reform. Government Printing Office, Washington, DC (1983)

Wilson, W.J.: When work disappears : the world of the new urban poor. Knopf, New York (1996)

Woirol, G.R.: The technological unemployment and structural unemployment debates. Greenwood Press, Westport (1996)

Zuboff, S.: In the age of the smart machine: the future of work and power. Basic Books, New York (1988)

Michael J. Handel is associate professor of Sociology at Northeastern University in Boston, Massachusetts, USA. He studies trends in labor market inequality and job skill requirements, particularly the impacts of changes in technology. His research has examined questions of skills mismatch and the impact of computers and employee involvement practices on wages, skills, and employment. He recently completed a book for the World Bank based on a skills survey in thirteen countries, Accounting for Mismatch in Low- and Middle-Income Countries: Measurement, Magnitudes and Explanations (with Alexandria Valerio and Maria Laura Sánchez Puerta). He has also compared trends in job skill requirements across all advanced economies in research published by the OECD. He is currently advising the U.S. Bureau of Labor Statistics on the development of the Occupational Requirements Survey. Michael J. Handel received a Ph.D. in Sociology from Harvard University. 